\title{
MENGASAH KEPEDULIAN MASYARAKAT DI TENGAH PANDEMI COVID-19 UNTUK PERSIAPAN MENGHADAPI ERA NEW NORMAL
}

\author{
SHARPEN PEOPLE'S IN THE MIDST OF THE COVID -19 PANDEMIC \\ FOR PREPARE THE NEW NORMAL ERA
}

\author{
Ning Maftuhah, Eni Zulfa Hidayah \\ Institut Agama Islam Negeri Jember \\ Ningmaftuhah145@gmail.com
}

\begin{abstract}
ABSTRAK
Covid-19 melanda banyak Negara di dunia termasuk Indonesia. Hampir seluruh negara di hantui oleh virus ini. Awal mula virus ini muncul dari daerah Wuhan Cina. Virus ini menyebar dengan cepat dan mematikan. Penularannya melalui kontak fisik ditularkan melalui mulut,mata dan hidung. Covid-19 berdampak kepada kehidupan sosial dan melemahnya perekonomian masyarakat. Latar belakang penulisan ini karena banyak masyarakat Indonesia yang menganggap covid ini tidak ada covid ini sebagai suatu konspirasi atau menganggap covid tidak berbahaya. Tujuan dari penelitian ini adalah membahas bagaimana persiapan serta penanggulangan terhadap adanya virus yang sedang mewabah di seluruh dunia ini. Metode penelitian ini menggunakan metode deskriptif kualitatif. Hasil penelitian disimpulkan dampak covid 19 menimbulkan masalah sosial pelemahan ekonomi masyarakat dan negara,untuk mencegah penyebaran covid-19 diperlukan kerjasama pemerintah, masyarakat, tokoh agama untuk saling bantu membantu, bahu membahu dan saling mengingatkan satu sama lain bersama melawan covid-19.
\end{abstract}

Kata Kunci: Penyebaran Covid-19, Era New Normal, Persoalan Sosial dan Ekonomi

\section{ABSTRACT}

Covid-19 hit many countries in the world including Indonesia. Almost all countries are haunted by this virus. The origin of this virus emerged from the Wuhan area of China. This virus spreads rapidly and is deadly. Transmission through physical contact is transmitted through the mouth, eyes and nose. Covid-19 has an impact on social life and the weakening of the people's economy. The background of this writing is because many Indonesians think that Covid does not have Covid as a conspiracy or think that Covid is not dangerous. The purpose of this research is to discuss how to prepare and treat the virus that is currently endemic throughout the world. This research method uses a qualitative descriptive method. The results of the study concluded that the impact of covid 19 caused social problems, weakening the economy of the community and the state, to prevent the spread of covid-19, cooperation from the government, community, religious leaders is needed to help each other, work hand in hand and remind each other together against Covid-19.

Keywords: Covid-19, New Normal Era, Social and Economic Problems. 


\section{PENDAHULUAN}

Wabah COVID-19 ini sudah menyebar di seluruh belahan dunia salah satunya negara Indonesia. Virus COVID-19 ini sudah banyak merenggut korban jiwa, tidak hanya merenggut korban jiwa, virus ini juga merenggut kebahagiaan dan ekonomi masyarakat. Penyebaran virus sangat cepat pada tanggal 2 maret 2020, Indonesia melaporkan kasus konfirmasi COVID-19 sebanyak 2 kasus. Sampai dengan tanggal 25 Maret 2020, Indonesia sudah melaporkan 790 kasus konfirmasi COVID-19 dari 24 provinsi. Oleh karena itu, penelitian ini dilakukan untuk melakukan penanggulangan dan mengasah kepedulian masyarakat kepada diri sendiri dan orang lain di tengah pandemi COVID-19. Karena vaksin virus ini belum tersedia, solusinya adalah dengan mematuhi protokol kesehatan menjadi satu-satunya cara yang efektif sebagai tindakan pencegahan penyebaran.

Berdasarkan bukti ilmiah, COVID-19 dapat menular dari manusia ke manusia melalui percikan batuk/bersin, tidak melalui udara. Orang yang paling beresiko tertular penyakit ini adalah orang yang melakukan kontak erat dengan pasien COVID-19 termasuk yang merawat pasien COVID-19. Rekomendasi standar untuk mencegah penyebaran infeksi adalah melalui cuci tangan secara teratur menggunakan sabun dan air bersih, menerapkan etika batuk dan bersin, menghindari kontak secara langsung dengan ternak dan hewan liar serta menghindari kontak dekat dengan siapapun yang menunjukkan gejala penyakit pernapasan seperti batuk dan bersin. Selain itu, menerapkan pencegahan dan pengendalian infeksi saat berada difasilitasi kesehatan terutama unit gawat daruryat (Kemenkes,2020).

Virus covid-19 ini sangat meresahkan masyarakat di seluruh dunia. Tanda dan gejala umum infeksi covid-19 antara lain gejala gangguan pernapasan akut seperti demam, batuk dan sesak napas. Masa inkubasi rata-rata 5-6 hari dengan masa inkubasi terpanjang 14 hari. Pada kasus COVID-19 yang berat dapat menyebabkan pneumonia, sindrom pernap asan akut, gagal ginjal dan bahkan kematian. Tanda-tanda dan gejala klinis yang dilaporkan pada sebagian besar kasus adalah demam, dengan beberapa kasus mengalami kesulitan bernapas, dan hasil Rontgen menunjukkan infiltrat pneumonia luas di kedua paru (Kemenkes,2020).

Virus ini bisa menyerang siapa saja seperti lansia(golongan lanjut usia), orang dewasa, anak-anak dan bayi termasuk ibu hamil dan menyusui. Infeksi virus Corona disebut COVID-19 (Corona virus disease 2019) dan pertama kali ditemukan di kota Wuhan,Cina pada akhir Desember 2019. Virus ini menular sangat cepat dan telah menyebar kehampir semua negara, termasuk Indonesia, hanya dalam waktu beberapa bulan. Hal tersebut membuat beberapa Negara menerapkan kebijakan untuk memberlakukan lock down dalam rangka mencegah penyebaran virus Corona. Di Indonesia sendiri, diberlakukan kebijakan Pembatasan Sosio Berskala Besar (PSBB) untuk menekan penyebaran virus ini.

Di Indonesia pemerintah membuat kebijakan Pembatasan Sosial Berskala Besar(PSBB), PSBB adalah istilah kekarantinaan kesehatan di Indonesia yang didefinisikan sebagai pembatasan kegiatan tertentu penduduk dalam suatu wilayah yang diduga terinfeks penyakit atau terkontaminasi sedemikian rupa untuk mencegah kemungkinan penyebaran penyakit atau kontaminasi.

Setelah melakukan wawancara didesa tempat pengabdian selama KKN DR masih 
banyak warga yang kurang sadar dengan bahayanya virus ini. Mereka menganggap bahwa virus ini tidak ada hanya konspirasi. Dan masih banyak masyarakat yang tidak mematuhi protokol kesehatan yang dianjurkan oleh pemerintah.Program yang dilakukan peneliti selama melakukan pengabdian adalah melakukan sosialisasi COVID-19 kepada masyarakat terutama masyarakat yang hidup di daerah pelosok yang minim akan informasi ter update karena terbatasnya media yang ada di daerah tersebut. Hasil dari penelitian ini masih banyak masyarakat yang kurang paham dengan virus Covid-19 ini dan juga banyak dari kalangan masyarakat menganggap Virus ini tidak ada virus ini hanya konspirasi. Oleh karena itu, peneliti mengadakan sosialisasi tentang COVID-19, mengajak masyarakat untuk mematuhi protokol yang dibuat oleh pemerintah.

\section{METODE}

Untuk membangun masyarakat dan memecahkan permasalahan-permasalahan didalam masyarakat dan mencapai tujuan yang telah dirumuskan sebelumnya, harus menggunakan metode yang tepat. Pelaksanaan pengabdian masyarakat ini dilakukan dalam beberapa langkah yang melibatkan metode penelitian lapangan berupa:

1. Observasi tempat KKN DR

2. Identifikasi masalah yang dilakukan sebagai langkah awal untuk merumuskan apa saja kegiatan yang akan dilakukan selama kegiatan KKN DR berlangsung

3. Melakukan survei lapangan di daerah yang ada di Bondowoso sebagai tempat dilaksanakannya kegiatan pengabdian.Kemudian melakukan proses Wawancara dan diskusi dengan pihak Desa untuk identifikasi permasalahan tentang COVID-19 yang ada disana.

4. Perancangan program kerja yang akan dilaksanakan pada saat pengabdian selama melaksanakan kegiatan KKN DR.

Dalam pengabdian ini peneliti mengadakan penanggulangan dan pencegahan Covid-19 seperti mengadakan sosialisasi COVID-19, penyemprotan disinfektan, pembagian masker dan menghimbau kepada masyarakat untuk mematuhi protokoler kesehatan ketika berada di keramaian.

Pengabdian ini menggunakan pendekatan community Development, yaitu pendekatan yang berorientasi kepada upaya-upaya pengembangan pemberdayaan masyarakat dengan menjadikan masyarakat sebagai subyek sekaligus obyek pembangunan dan melibatkan mereka secara langsung dalam berbagai kegiatan pengabdian masyarakat sebagai upaya peran serta mereka dalam pembangunan demi kepentingan mereka sendiri.

\section{HASIL DAN PEMBAHASAN}

Selasa 18 agustus 2020 mengadakan sosialisi COVID-19 di Yayasan MIFTAHUL ULUM Sucolor, kecamatan Maesan kabupaten Bondowoso. Pada jam 07.00 saya bersama Mahasiswa KKN DR kelompok lain yang berdomisili di Bondowoso berangkat ke Yayasan MIFTAHUL ULUM, kami menempuh perjalanan sekitar satu jam untuk menuju ke yayasan tersebut. Jam 08.00 kami sampai di yayasan tersebut dan langsung menemui kepala sokalah MI untuk meminta izin meluai kegiatan. Setelah meminta izin untuk mengajar kami langsung memasuki kelas kelas yang telah ditentukan sebelumnya. Saya mendapat bagian untuk melakukan sosialisasi di kelas $2 \mathrm{MI}$. 
sesampainya dikelas saya langsung disambut baik oleh anak-anak disana, saya langsung memperkenalkan diri kepada mereka kemudian memulai kegiatan sosialisasi .sosialisasi tersebut berisikan tentang bagaimana pencegahan virus corona dan gejala-gejala yang ditimbulkan oleh virus COVID-19. Anak-anak disana sangat antusias dalam mengikuti sosialisasi tersebut. Setelah sosialisasi saya mengadakan game, game tersebut seperti memberikan pertanyaan yang telah saya sosialisasikan tadi. Bagi anak yang dapat menjawab pertanyaan akan mendapatkan hadiah, kegiatan tersebut berlangsung salam satu jam. Program ini bertujuan agar murid-murid di yayasan tersebut mengetahui apa itu virus corona dan cara pencegahannya. Sosialisasi COVID-19 di Yayasan MIFTAHUL ULUM merupakan salah satu cara untuk mencegah COVID-19, sehingga diharapkan dapat dijadikan langkah awal untuk pencegahan Covid-19 dan mengurangi angka kasus COVID-19 dan angka kematian yang disebabkan oleh COVID-19.

Dengan sosialisasi ini pula diharapkan siswa siswi sedikit demi sedikit mulai memahami gejala COVID-19 cara pencegahannya dan bahannya.

Beberapa faktor pendukung kegiatan tersebut antara lain :

1. Para peserta sosialisasi memiliki kemauan yang besar untuk mendapatkan informasi dan pengetahuan mengenai cara pencegahan, gejala dan bahaya COVID-19.

2. Kegiatan sosialisasi COVID-19 sangat didukung oleh pihak Yayasan secara langsung maupun tidak langsung berpartisipasi secara aktif dalam kegiatan tersebut.pihak yayasan menyediakan fasilitas tempat kegiatan yang cukup representative untuk melaksanakan kegiatan sosialisasi tersebut. lain:

Beberapa kendala yang dihadapi pada saat kegiatan sosialisasi COVID-19 antara

1. Adanya keterbatasan dalam fasilitas pendukung untuk melakukan sosialisasi, dan presentasi ,salah satunya tidak adanya LCD proyektor.

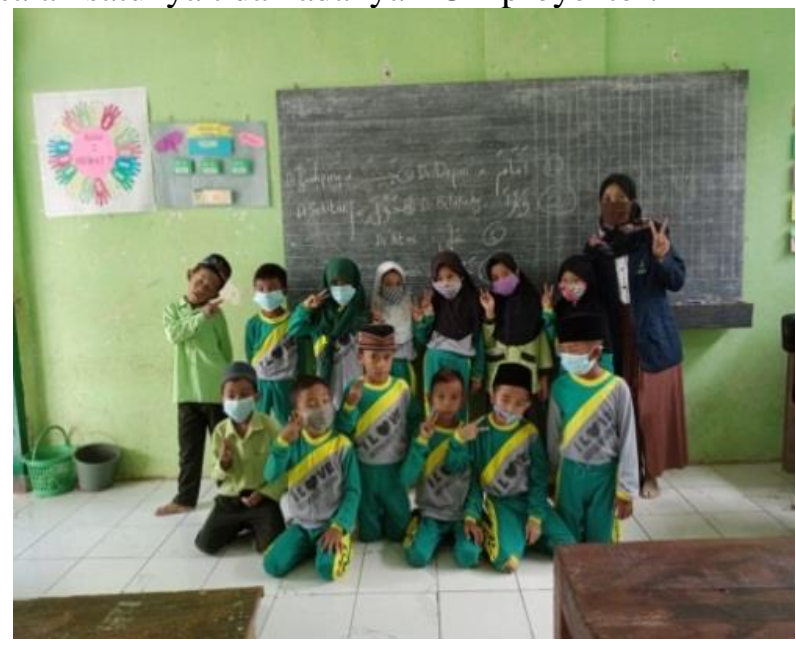

Gambar 4.

Sosialisasi COVID-19 
1. Penyemprotan disinfektan

Jumat 4 september 2020 saya melakukan penyemprotan disinfektan di sekitar rumah. Penyemprotan ini dilakukan pada sore hari. Karena sasaran utama penyemprotan ini adalah mushalla, dimana pada hari jumat masyarakat dirumah biasanya melakukan pengajian. Untuk itu saya melakukan penyemprotan disinfektan untuk persiapan bagi masyarakat dalam melaksanakn pengajian. Penyemprotan ini menggunkan bahan bahan sebagai berikut pemuth baju dan deterjen. Saya menyemprot rumahrumah warga yang menjadi sasrannya adalah ganggang pintu dan pilar karena benda tersebut yang sering di pegang oleh orang-0rang dan berpotensi mengandung banyak virus.

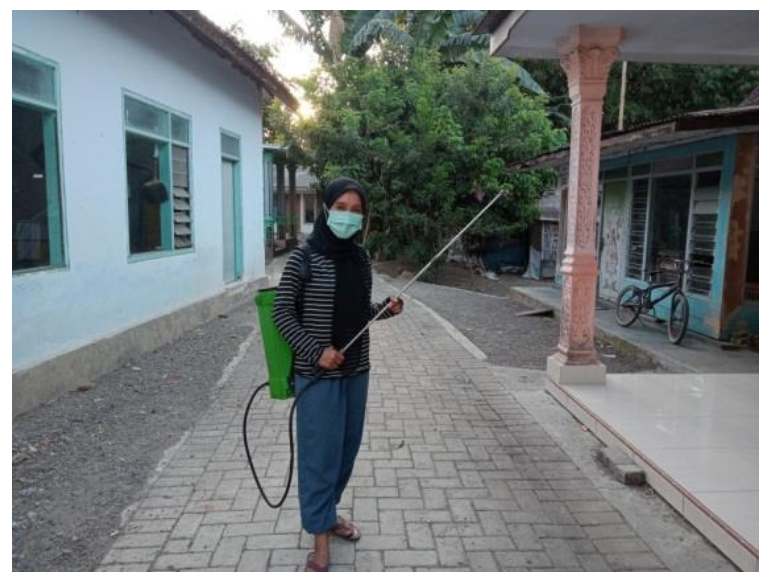

Gambar 5.

Penyemprotan disinfektan

2. Pembuatan pamflet

Rabu 12 agustus 2020 saya membuat pamflet untuk disebarkan dimedia social dan ditempel ditempat-tempat berkumpulnya orang-orang. Saya membuat pamflet menggunakan aplikasi canva dan bahan-bahannya mengutip dari google. Pamflet tersebut berisikan pengertian corona, gejala kliniks dan pencegahan virus corona. Setelah pembuatan pamflet selesai saya langsung mengupload ke media social seper instagram dan facebook guna untuk memberikan himbauan kepada masyarakat yang menggunakan media social. Tujuan dalam pembuatan pamflet ini adalah memberikan pengetahuan terhadap masyarakat tentang gejala klinis COVID-19 dan cara pencegahannya. Karena pada saat melakukan wawancara bersama masyarakat sekitar banyak dari mereka yang masih kurang paham tentang virus ini apa saja gejalanya, dan bagaimana pencegahannya.

Hasil dari pengabdian selama melaksanakan KKN DR adalah rasa peduli masyarakat terhadap diri dan orang lain dimasa pandemi ini meningkat. Setelah melakukan kegiatan sosialisasi dan penyebaran pamflet masyarakat menjadi sangat antusias dalam melaksanakan protokol kesehan dan menjaga diri mereka sendiri dan orang lain. Masyarakat menjadi lebih sadar bahwa virus ini sangat berbahaya dan mematikan. Kepala sekolah di Yayasan MIFTAHUL ULUM menuturkan setelah melakukan kegiatan sosialisasi COVID-19 oleh mahasiswa KKN DR murid siswa siswi yang ada di Yayasan tersebut lebih memperhatikan kebersihan dan mematuhi protokol 
kesehatan selama pembelajaran berlangsung.

\section{SIMPULAN}

Mahasiswa KKN DR telah melaksanakan kegiatan pengabdian kepada masyarakat dengan tema peduli COVID-19. Kegiatan ini dilakukan agar mahasiswa mempunyai pengalaman bekerja yang berharga melalui keterlibatan dalam masyarakat yang secara langsung menemukan, merumuskan, memecahkan dan menanggulangi masalah pembangunan secara pragmatis dan interdisipliner. Dan juga kegiatan ini bertujuan untuk membimbing masyarakat dalam menghadapi masalah sosial ekonomi di masa pandemi ini. Hasil dari pengabdian ini adalah masyarakat lebih mamahami tentang tentang COVID-19, masyarakat lebih disiplin dalam menjalankan protoko kesehatanl yang dianjurkan oleh pemerintah. Semoga pemerintah lebih memperhatikan para petani karena petani banyak mengeluh akibat pandemi ini harga pupuk melonjak tinggi dan hasil panen yang murah dan pemerintah tidak memberikan perhatian terhadap hasil panen petani.

Demikian laporan pengabdian KKN DR tentang kepedulian COVID-19 di daerah Bondowoso, kami buat dengan sebenarnya-benarnya tanpa ada hal yang ditambahkan maupun dikurangi. Semoga laporan KKN DR ini dapat diterima walaupun masih banyak kekurangannya.

Terimakasih sebesar-besarnya kepada pihak LP2M dan DPL yang sudah membimbing kami selama melaksanakan kegiatan KKN DR.

\section{DAFTAR PUSTAKA}

Nawawi, H. Hadari.1983. metode penelitian deskriptif. Yogyakarta Gajah Mada university press.

Nazir, M. 1998. Metode penelitian. Ghalia Indonesia: Jakarta. 